\title{
Understanding Institutional Racism
} Sarah Pearce

The concept of institutional racism is under attack. There was a brief period after the publication of the Macpherson Report in 1999 and the Race Relations (Amendment) Act of 2000 in which it appeared to have gained wide acceptance as a useful term for a pressing problem. Since then, a number of public figures have suggested that the use of the term institutional racism is unhelpful, and it is possible that the whole idea of institutions looking at their working practices to ensure they are fair may fall out of favour. And the brief period in which complex definitions of racism were accepted in the mainstream media may now be at an end.

The Macpherson Report's definition of institutional racism is worth repeating yet again. It is

the collective failure of an organisation to provide an appropriate and professional service to people because of their colour, culture or ethnic origin. It can be detected in processes, attitudes and behaviour which amount to discrimination through unwitting prejudice, ignorance, thoughtlessness and racist stereotyping which disadvantage minority ethnic people. (Macpherson, 1999: para 6.34)

There is good reason why this paragraph has been so often quoted. It offers a very different view of racism from the one that many, mostly white, people understand. It suggests that racism is not just the violent attack in the park, nor the obscene graffiti in the street. It is something of which ordinary people may be a part. Further, this definition rejects the importance of intentionality: it is the outcome of actions, not the intention of them, which must be considered when determining the existence of racism (Gillborn, 2005). Again, this turns many white people's understanding of racism on its head, and provoked furious debate at the time, which continues today. Yet despite ten years of discussion, there is evidence that many education professionals still understand racism in its crudest forms, and do not acknowledge the subtler workings of institutional racism (Gillborn, 2002; LDA, 2004; Pearce 2005).

To reject the term institutional racism would be to risk returning to an understanding of racism which focuses on individuals: racism as an aberration. It would also mean losing what gains we have made in re-thinking working practices. It may be that tackling racism at its roots is no longer the key issue in government circles it once appeared. But schools' slow progress in meeting the requirements of the Race Relations (Amendment) Act is still perplexing. It may be that there is a genuine lack of understanding about what constitutes institutional racism.

In an earlier edition of RET, Carl Parsons and Simon Hepburn (2007) offered useful detailed advice to schools wishing to follow both the letter and the spirit of the law. I agree that the focus should remain on institutions, but I am concerned that this can mean that some individuals are left unsure what part they play. In this article, therefore, I want to offer some illustrations of teachers confronting aspects of institutional racism in their schools. They are not intended to point the finger at any individual or institution. Instead, I hope that having concrete examples may help colleagues and student teachers who are grappling with the concept and how their 
actions as individuals and members of a staff body can support or dismantle it. They are drawn from a larger study of a group of nine beginning teachers on a BA(Ed) course, who were interviewed at various stages in their early careers. The teachers were all women, from a range of ethnic backgrounds, and aged between their early twenties and early forties. The stories included here were told by the women during interviews following their final school practice or at the end of their first year of teaching.

Parsons and Hepburn note the importance of schools working to ensure that people from a range of cultural backgrounds are in schools, 'to provide role models and to engage with the cultures of the pupils' (2007:18). The experiences of one student illustrate what can happen when diversity in the staffroom is not the norm.

Farida was a Londoner in her twenties, and from a Somali background. She was a committed Muslim and wore a hijab, which covers all of the head but the face. On her final teaching practice, she described why she stopped going into the staffroom after the first couple of weeks, preferring to spend her breaks with the children in the playground:

You just feel out of place. Well, I feel out of place. And you look at the staffroom, you look at you know, who's there, who's having their lunch there and it's all of the white teachers, and I just feel that sometimes, I mean they're all really nice people, but - are there things they would like to know more about me, you know because obviously they would have questions... I know that wherever I go now wearing the hijab they have these... instant thoughts or I'll remind them of something or somebody that they've seen before, and that puts up a barrier, but then after they see what my character is like, I've noticed how people open up to me a bit more. And it's just a constant, like, having to prove myself, and then not really, but then people just don't know what I'm like so... I just got tired.

Farida is conscious that her hijab creates questions and may evoke negative stereotypes in the minds of her colleagues. They seem inhibited with her, and often do not engage with her at all. She has noticed that this barrier can break down over time, as people come to know her as an individual, but she gets tired of having to do the work that is necessary to get to this stage. Her response is to withdraw herself physically from the staffroom, and also emotionally from her teaching colleagues, a response which leaves her isolated and lacking in a support network. This situation illustrates the importance of a focus on outcomes as opposed to intentions in understanding institutional racism. There is no suggestion that Farida experienced any overt racism, but the outcome of the staff's attitude to her was that she had a more difficult time on her teaching practice solely because of her religious background.

While minority students sometimes feel unwelcome in schools, white students can find themselves included with surprising and unearned warmth. Susan was a white teacher in her forties when she started work in a school which had a fairly high proportion of African-Caribbean teachers. She told me that she had immediately been aware that there was a distinct divide between the white and black members of staff. When I asked her to explain, she gave this example of what happened when she was asked to join a focus group on teaching:

Susan: It was all white teachers. So they asked me to come along. One of the teachers...asked me to come.

SP: And they were all white?

Susan: Yeah.

SP: Even though it's kind of fifity-fifty [in terms of white and black teachers] in the school? 
Susan: Yeah ... But that's the kind of thing I mean. I've only spoken to her a few times, and she asked me to come along. It's that kind of thing.

Susan appears to be suggesting here that her presence in the focus group was considered desirable because, being white, she was regarded as one of them. The teacher organising the group did not know her personally, but chose her above other, ethnic minority, colleagues, even though this meant that the composition of the group did not reflect the ethnic mix of the school as a whole.

The decision to invite Susan was an individual one: it was not taken by the school as an institution. And the teacher's intention in inviting her rather than other colleagues may have been innocent: she was a hard-working, well-respected NQT. And yet the outcome was that when the multi-ethnic staff had its views sought, the minority ethnic colleagues were not given the opportunity to speak. Susan's comment that 'it's that kind of thing', suggests that white staff members taking precedence over minority ethnic colleagues was a common occurrence. It is this pattern of preferential treatment that suggests that this is an example of institutional racism.

My third example is drawn from a school in which the majority of the children and all of the teachers were white. During her final placement there, Debbie was disturbed by the attitude of several teachers to one girl in her class, Shakira. The girl had erratic attendance and was assigned to the lowest ability groups in all subjects in her Year 2 class:

Everyone was aware of the difficulties she had but it was quite overlooked. She didn't make a fuss, she was pleasant enough. But I didn't feel her needs were particularly met very well.

In some distress she told me of an incident in which Shakira, who had a white mother and a black father, had called her African-Caribbean friend a racist name, and when Debbie challenged her, had broken down, expressing very negative feelings about being black. Debbie spoke to the class teacher about it but said, 'she sort of dismissed it a bit really.' Debbie was shaken by the incident, however, and it made her reflect on the extent to which ethnic diversity was acknowledged in the school:

I think her saying that and seeing that in the classroom made me realise how sort of white the curriculum that was being taught is. And it's something that I could complain about, but I really, really witnessed it in action there.

On another occasion, Debbie was waiting with her colleagues for children to get on the coach for a school trip, and Shakira was late. Debbie was anxious, both that Shakira should be part of the trip, and that she should not incur more of the staff's disdain:

The staff were going, 'well, surely you didn't expect her to be on time for it?' And I just think comments like that are so unhelpful...and I got really angry with them [Shakira's parents] to myself, 'don't give these people something to complain about because it really doesn't take very much.' You know, if someone else hadn't been there on time they wouldn't be saying it, and why should they make more effort not to play...you know.

Debbie is very aware that some of her colleagues have negative stereotypes about the kind of family Shakira comes from, perhaps because of both her class and race background. While such fragments cannot give us a full picture of Shakira's experience of schooling, Debbie felt sure that her ethnicity played a part in determining her teachers' negative perceptions of her. And she was uncomfortable that the curriculum in the school focused on the experiences of white Europeans, which also made it difficult for children like Shakira to feel accepted and 
have their voices heard. Again, there is no suggestion of intentional racism here. But again, that is not the key issue: the pattern of indifference and low expectations points to institutional racism.

What can individual teachers and schools do to avoid the scenarios illustrated above? They all suggest that minimal compliance with the Race Relations (Amendment) Act, which may be all that is being attempted in some schools (Parsons, 2009), will not be enough to change the experience of schooling for many minority ethnic staff and pupils. Farida and Susan's experiences suggest that simply having a multi-ethnic staff will not lead to equality, integration and open dialogue between individuals from different ethnic groups unless priority is given, in terms of time and space, to such developments.

Debbie's experience points to the need for a thorough analysis of attainment to ensure ethnic minority children are not the victims of low expectations in Shakira's school, and also staff development on stereotyping and a revamp of the curriculum. Such initiatives take time, and time is in short supply in schools today. They can also be personally uncomfortable, even painful. But institutions will not change unless individuals analyse their own attitudes and behaviour and recognise the need for change. And individual teachers, working together over time, can push for and make genuine improvements for both staff and pupils which far exceed the bureaucratic box-ticking exercise which might otherwise be all that is achieved.

\section{References}

Gillborn, D. (2002) Education and institutional racism (Institute of Education, University of London)

Gillborn, D. (2005) Education policy as an act of White supremacy: Whiteness, critical race theory and education reform, Journal of Education Policy vol. 20, no. 4

London Development Agency (2004) Educational Experiences and Achievements of Black Boys in London Schools 2000 2003 a report by the Education Commission (www.Ida.gov. uk/upload/rtf/Findings.rtf) accessed 8 July 2009

Macpherson, W. (1999) The Stephen Lawrence Inquiry (London. HMSO)

Parsons, C. and Hepburn, S. (2007) What should schools and local authorities be doing about institutional racism? Race Equality Teaching, no. 25

Parsons, C. (2009) Explaining sustained inequalities in ethnic min school exclusions in Eng- passive racism in a neoliberal grip. Oxford Review of Education, vol. 35, no. 2

Pearce, S. (2005) You Wouldn't Understand: white teachers in multi-ethnic classrooms (Stoke on Trent, Trentham) 